\title{
ДІЄСЛОВА ЛЕКСИКО-СЕМАНТИЧНОГО ПОЛЯ «АГРАРНЕ ВИРОБНИЦТВО (РОСЛИННИЦТВО)» В УКРАЇНСЬКІЙ МОВІ: КРИТЕРІЇ ІДЕНТИФІКАЦІЇ ТА ТИПОЛОГІЯ
}

Познанський Р. В. Дієслова лексико-семантичного поля «аграрне виробництво (рослинництво)» в українській мові: критерії ідентифікації та типологія

Предметом статті стали українські дієслова, які позначають процеси аграрного виробництва, зокрема обробітку грунту, висаджування рослин та догляду за ними, збирання урожаю тощо. Простежуються семантичні особливості таких дієслів, окреслюються критерії їх ідентифікації, виявлясться їх типологія.

Ключові слова: дієслово, лексико-семантичне поле, типологія дієслів.

Познанский Р. В. Глаголы лексико-семантического поля «аграрное производство (растениеводство)» в украинском языке: критерии идентификации и типология.

Предметом статьи стали украинские глаголы, обозначающие процессы аграрного производства, в частности возделывания почвы, высаживания растений и ухода за ними, сбор урожая и под. Прослеживаются семантические особенности таких глаголов, очерчиваются критерии их идентификации, определяется их типология.

Ключевые слова: глагол, лексико-семантическое поле, типология глаголов. 
Poznanskyy R. V. Verbs of Lexical and Semantic Field «Agricultural Production (Crop Production)» in the Ukrainian Language: Identification Criteria and Typology.

The article studies the Ukrainian verbs which denominate agricultural production processes, in particular soil cultivation, planting crops and looking after them, harvesting etc. Semantic peculiarities of the above verbs are tracked, their identification criteria are traced. The typology of these verbs is also examined.

Key words: verb, lexical and semantic field, typology of the verbs.

Передумовами вивчення дієслів як елементів лексичної системи мови $\epsilon$, безперечно, виявлення їх типології, тобто їх місця й ваги у вербальному блоці загальномовного лексикону. Метою пропонованої статті є виявлення критеріїв ідентифікації та типології дієслів лексикосемантичного поля «аграрне виробництво (рослинництво)», які не були ще преметом спеціального наукового дослідження. Досягнення мети передбачає розв'язання низки конкретних завдань, зокрема окреслити поняття лексико-семантичного поля, запропонувати критерії ідентифікації дієслів лексико-семантичного поля «аграрне виробництво (рослинництво)», виявити внутрішню структурованість названого лексико-семантичного поля, його членування на ядро та периферію, а також на мікрополля. Дослідження лексичної системи в такому ракурсі передусім зводиться до виявлення різноманітних лексичних об'єднань, груп тощо, що вилилося свого часу в теорію лексико-семантичних чи семантичних полів (I. Трір, Г. Іпсен, В. Порциг, Г. Мюллер, Ю. Апресян, Л. Васильєв, Т. Уфімцева, Ф. Філін, Ю. Караулов, Е. Косеріу та ін.). Предметом дослідження теорії поля в сучасній лінгвістиці є групи мовних одиниць, які об'єднуються загальним значенням (семантичний принцип), загальною функцією (функціональний принцип) або комбінацією двох ознак (функціонально-семантичний принцип). Сучасні визначення поля відзначаються різноманітністю. Лексико-семантичними полями можна вважати семантичні групи слів однієї частини мови, семантичноспіввідносні групи слів різних частин мови, функціонально-семантичні поля та парадигми синтаксичних конструкцій, різні типи семантикосинтаксичних синтагм тощо [Див.: 8, с. 126]. Незважаючи на розбіжності в тлумаченні терміна «семантичне поле», невід'ємними ознаками лексико-семантичного поля $є$ передусім монокатегорійність і наявність архісеми, тобто спільного (інтегрального) лексичного значення.

Аналізуючи різноманітні підходи до класифікації дієслів, виявлення їхньої типології, зокрема й структурування дієслівної лексики на лексикосемантичні поля, погоджуємося з висновками дослідників про відсутність вичерпної й загальноприйнятої типології дієслів у мові. Так, наприклад, Л. Васильєв, розглядаючи типологію дієслів за семантичним принципом, зазначає: «Загальноприйнятної класифікації дієслівної лексики, як відомо, немає, та й навряд чи вона взагалі можлива, оскільки будь-яка класифікація зумовлюється якимись принципами й аспектами, а вони визначаються 
цілями й завданнями дослідження» [4, с. 39]. Беручи до уваги не тільки семантичні, а й граматичні принципи класифікації дієслів, О. Соколов також підкреслює: «Одним із складних питань є визначення принципів класифікації дієслівних лексем. Існують численні досвіди таких класифікацій, хоч задовільного вирішення не знайдено» [14, с. 100-101]. Водночас такі твердження ще не означають неможливості здійснення узагальнювальної типології дієслівної лексики на різноманітних, але єдино визнаних засадничих принципах. Тим більше типологія дієслів у межах одного лексико-семантичного поля - цілком здійсненна перспектива, адже саме поняття лексико-семантичного поля, як ми уже зазначали, передбачає наявність певних критеріїв відбору відповідної лексики.

При класифікації дієслів у семантичному аспекті використовуються головним чином три принципи: 1) денотативний (або тематичний); 2) парадигматичний; 3) синтагматичний.

Денотативний підхід є найбільш традиційним у сучасній лінгвістиці. Він ураховує передусім природне, онтологічне розчленування предметів, ознак, властивостей, дій, процесів, станів тощо, яке відображене у структурі мови. Так, у межах дієслівної лексики вже давно виділяються та вивчаються такі групи слів, як дієслова руху, дієслова мовлення, дієслова мислення, дієслова почуттів та деякі інші. «Виділення таких класів, - як влучно підмітив Л. Васільєв, - опирається на інтуїцію мовців (зокрема, на інтуїцію дослідника), на їх знання про реальну дійсність, тобто в кінцевому результаті на екстралінгвістичні фактори» [4, с. 39]. Водночас цей принцип не абсолютизується, а, як слушно зауважив дослідник, повинен доповнюватися парадигматичним та синтагматичним принципами. При цьому парадигматичний підхід до типології лексики здійснюється шляхом виокремлення у значеннях слів (при їх порівнянні 3 ідентифікатором) тотожних і диференційних компонентів. Парадигматичний принцип враховує, на відміну від тематичного, не тільки денотативний, але й сигніфікативний аспект значень (сем), які класифікуються. Так, наприклад, каузативні й некаузативні, статальні та інхоативні, результативні і нерезультативні дієслова, а також інші схожі групи дієслівної лексики, вичленовуються тільки за парадигматичним принципом, шляхом аналізу сигніфікативних (тобто категорійних, а не предметних) компонентів у значеннях дієслів. Широко використовується при класифікації дієслів синтагматичний принцип, який грунтується на врахуванні кількості та якості, тобто семантичного наповнення, дієслівних валентностей [Див., напр.: 4, с. 40 і далі; 12; с. 1 та ін.]. Так, наприклад, В. Богданов, окреслюючи 4 типи предикатів та 14 семантичних функцій (семантичних валентностей), виокремлює в російській мові 42 типи предикатних виразів, тобто 42 абстрактні предикативні семантичні синтагми [3, с. 57-58].

Отже, застосування різноманітних принципів чи їх комбінацій до 
класифікації й типології лексики призводить до виділення ії різноманітних лексико-семантичних, лексико-тематичних груп та полів. У цьому аспекті постає необхідність чітко визначити критерії ідентифікації дієслів лексикосемантичного поля «аграрне виробництво (рослинництво)», які $\epsilon$ предметом нашого дослідження.

Необхідність вироблення таких критеріїв зумовлена передусім тим, що дієслова лексико-семантичного поля «аграрне виробництво (рослинництво)» не ставали предметом спеціальних студій і не окреслювалися як окрема цілісна група дієслів у жодній з відомих нам типологій дієслівної лексики. Так, наприклад, при вивченні дієслів конкретної фізичної дії з семантикою створення об'єкта А. Шумейкіна виявляє внутрішню типологію таких вербативів, у якій типологізувальні ознаки грунтуються на виявах дієслівної валентності: «Спільною, чи інтегральною, ознакою, на основі якої дієслова об'єднуються в цю лексико-семантичну групу, виступає категорійнолексична сема мети дії «створювати / робити / будувати / ставити». Конкретизація семантичної теми створення відбувається через лексичні категорії суб'єкта та об'єкта, способу, матеріалу і знаряддя дії» [16, с. 7]. При цьому дієслова, які, на нашу думку, можна віднести до лексико-семантичного поля «аграрне виробництво (рослинництво)», потрапляють у цій типології до різних підгруп. Усе це зумовлює актуальність обраної теми.

Опираючись на теорію лексико-семантичних полів і груп, а також різні підходи до семантичної типології передусім дієслівної лексики, окреслимо низку вихідних положень ідентифікації та подальшої типології дієслів лексико-семантичного поля «аграрне виробництво (рослинництво)». Очевидним $є$ те, що в основу виділення таких дієслів мусить бути покладений онтологічний принцип, тобто їх детонативні компоненти значення, які повинні виступати інтегральними семами. Інакше кажучи, до лексикосемантичного поля «аграрне виробництво (рослинництво)» можуть належати тільки ті дієслова, які позначають різноманітні процеси чи стани, певною мірою пов'язані з господарською діяльністю людини в аграрній сфері.

У сучасній українській мові здійснено низку спроб аналізу лексем, що позначають різноманітні аспекти сільськогосподарської (аграрної) діяльності людини, включаючи як рослинництво, так і тваринництво. Прикметним $є$ те, що предметом дослідження в таких роботах майже завжди виступає винятково субстантивна лексика. Так, назви рослин та інших реалій, пов'язаних із рослинництвом, з погляду їх семантичної структури, функціонування, словотвірного потенціалу розглядаються останнім часом в низці студій як на матеріалі української мови чи їі діалектів, так і на матеріалі інших мов, зокрема й у порівняльному аспекті [Див.: 2; 6; 7; $9 ; 10 ; 11 ; 13 ; 15$ та ін.]. При цьому онтологічний принцип ідентифікації тих чи тих груп субстантивної лексики очевидний: до назв рослин, наприклад, належатимуть субстантиви (рідше - субстантивні словосполучення), які ○ Р. В. Познанський, 2013. 
позначатимуть ту чи ту назву рослини.

Визначення семантики дієслова на основі онтологічного принципу не настільки є однозначним, оскільки номінації тих чи тих процесів, які більшою чи меншою мірою стосуються рослинництва, не обов'язково є унікальними, як, скажімо, назви рослин - це тільки назви рослин (у прямому значенні). 3 цього погляду більшість дієслів позначають широкий спектр процесів, з яких тільки окремі вияви можна розцінювати як процеси в аграрному виробництві. Так, вербатив копати, який належить до дієслів конкретної фізичної дії, може позначати і процес первинного обробітку грунту, підготовки його до сівби («розпушувати землю лопатою, заступом тощо» [5, с. 453]), і процес збирання урожаю (копати картоплю), і процеси, загалом не пов'язані 3 аграрним виробництвом (копати яму, копати криницю, копати проти когось). Схожа семантична структура притаманна й багатьом іншим вербативам, які ми зараховуємо до лексико-семантичного поля «аграрне виробництво (рослинництво)» (пор., напр., дієслова вирочувати, поливати, збирати (врожсай), бризкати чи розсипати (добрива), виводити (новий сорт рослини), вивільняти (грунт), вигибати (рослини вигибають), вигортати (грунт з ями) тощо). На думку дослідників, актуалізація значення дієслова відбувається в основному в контексті, через що «синтагматичне оточення $є$ найефективнішим засобом розкриття семантики слова, тому показ сполучуваності не менш важливий для характеристики значення слова, ніж саме його тлумачення» [16, с. 7]. 3 іншого боку, не варто абсолютизувати синтагматику у визначенні семантики дієслова, адже не менш чисельна частина дієслівної лексики є більшою мірою однозначною i винятково належатиме до лексико-семантичного поля «аграрне виробництво (рослинництво)». Такими $\epsilon$, наприклад, дієслова орати, полоти, боронувати і под.

Отже, онтологічний критерій ідентифікації дієслів лексико-семантичного поля «аграрне виробництво (рослинництво)» $\epsilon$ вихідним. Інтегральною семою таких вербативів $є$ номінація дії, процесу чи стану, прямо чи опосередковано пов'язаної з рослинництвом. При цьому, на нашу думку, варто відносити до окресленого лексико-тематичного поля як дієслова, де ця сема формуватиме пряме, центральне значення багатозначного слова (на зразок орати), так і такі дієслова, де визначена нами сема перебуватиме на периферії лексико-семантичної структури вербативної лексеми (на зразок поливати). При цьому до аналізованих дієслів варто відносити й дієслова, де інтегральна сема «рослинництва» загалом може виявлятися тільки внаслідок актуалізації відповідних синтагматичних контекстів (наприклад, дієслово корчувати можна відносити до лексико-семантичного поля «аграрне виробництво (рослинництво)» тільки за умови, що метою такого процесу є підготовка землі під садіння рослин).

Виділення дієслів на основі такого підходу, на нашу думку, дасть 
змогу найбільш повно окреслити лексико-семантичне поле «аграрне виробництво (рослинництво)», виявити його внутрішню структуру, ядро та периферію, простежити інтерференцію цього поля з іншими лексикосемантичними полями дієслівної лексики української мови.

Загалом до лексико-семантичного поля «аграрне виробництво (рослинництво)» належать дієслова двох принципово різних типів. 3 одного боку, це вербативи, які позначають дії чи процеси аграрного виробництва, суб'єктами яких виступає людина: орати, боронувати, садити, сіяти, косити тощо. Такі дієслова становлять основу лексикосемантичного поля «аграрне виробництво (рослинництво)» i кількісно переважають. 3 іншого боку, інтегральна сема причетності до аграрного виробництва виявляється й у семантичній структурі дієслів, які позначають процеси, дії чи стани, що здійснюються без активної участі людини (в'янути, квітнути, дозрівати, брунькуватися, плодоносити, відмерзати тощо). На нашу думку, такі дієслова також повинні належати до лексикосемантичного поля «аграрне виробництво (рослинництво)», адже процеси чи дії, номіновані ними, є важливими в аграрному виробництві, оскільки вказують на різні етапи росту рослин, дозрівання урожаю, тобто загалом виступають маркерами певних етапів і процесів аграрного виробництва. Такі дієслова, очевидно, слід відносити до напівпериферії лексикосемантичного поля «аграрне виробництво (рослинництво)».

До периферії окресленого лексико-семантичного поля відносимо також дієслова, які належать до інших лексико-тематичних полів чи позначають найбільш узагальнені дії i процеси, однак в певному контекстуальному оточенні номінують процеси, дотично пов'язані із рослинництвом. Це, наприклад, дієслова на зразок адаптувати (у значенні адаптувати рослини до нових умов), асимілювати (у такому самому значенні), бактеризувати (піддавати дії бактерій; може стосуватися спеціальної обробки грунту) тощо.

Беручи до уваги послідовні етапи будь-якого виробництва як процесу, можна окреслити й загальну схему їх вербальних номінацій. Так, найбільш узагальнено така схема повинна включати такі комплекси процесів: 1) підготовка (заготівля) матеріалу, необхідного в процесі виробництва, та первинні обробки матеріалу; 2) безпосереднє виробництво продукції (може передбачати кількаступеневе виробництво 3 різними фазами й етапами); 3) зберігання та збут продукції. Аграрне виробництво у цьому аспекті відзначається своєю специфікою: безпосередні фази (етапи) аграрного виробництва в галузі рослинництва можна звести до такої схеми:

1. Різноманітні етапи обробітку грунту, унаслідок яких аграрій повинен отримати грунт, придатний для вирощування відповідних рослин.

2. Етапи підготовки насіння до садіння (сіяння), зокрема, його відбір, зберігання, просушування тощо.

() Р. В. Познанський, 2013. 
Водночас зазначимо, що наведені два перші етапи процесу аграрного виробництва можуть бути відсутніми чи модифікованими в окремих видах рослинництва, зокрема в садівництві чи лісівництві, де етап підготовки насіння зводиться до вирощування та щеплення саджанців, а етапам обробітку грунту загалом не приділяється уваги.

3. Безпосереднє сіяння (садіння) насіння, тобто внесення його різними способами в підготовлений для цього грунт.

4. Етапи догляду за ростом рослин, їх дозріванням, появою й дозріванням плодів тощо.

Цей етап є чи не найбільш тривалим, оскільки для окремих видів рослин не зводиться тільки до річного циклу (посадив навесні, а зібрав плоди восени), а до кількарічного чи й навіть кількадесятирічного (наприклад, вирощування виноградників, де до моменту збирання плодів для виготовлення якісних сортів вин повинно пройти кілька років, чи вирощування плодових дерев, збирати урожай з яких можна також лише через кілька, а то й кілька десятків років). До цього етапу аграрного виробництва слід зараховувати:

- процеси, пов'язані з обробітком рослин під час їх росту (обрізування пагонів, щеплення саджанців, прив'язування рослин (наприклад, бобових) до додаткових опор та ін.);

- процеси, пов'язані з поточним обробітком грунту, в якому ростуть рослини, зокрема й знищення шкідливих рослин, бур'янів (просапування, підгортання та ін.);

- процеси, пов'язані з внесенням у грунт добрив, обприскуванням рослин вітамінами чи отрутохімікатами задля знищення шкідників, підливанням рослин тощо;

- процеси, пов'язані з посиленим доглядом за рослинами під час несприятливих погодних і кліматичних умов, зокрема й процеси підготовки багаторічних рослин до зимівлі, догляд за ними взимку чи під час посухи тощо;

- процеси, пов'язані з підготовкою до збирання урожаю (наприклад, зрізування гички картоплі (картоплиння) чи інших рослин-коренеплодів).

У межах цього етапу варто також виокремлювати процеси, пов'язані 3 різними етапами росту рослин та дозріванням їх плодів, але які відбуваються без безпосередньої участі людини: брунькуватися, зав'язатися (у плід), квітнути, в'янути і под.

5. Різноманітні етапи збирання врожаю.

Отже, ми розглянули п'ять різноманітних фаз, етапів процесу аграрного виробництва у хронологічному аспекті: спочатку обробляється грунт i насіння, тоді садиться насіння, вирощуються рослини і збирається урожай. Однак такий погляд на хронологічно впорядковані фази аграрного виробництва не охоплює всіх процесів, з цим виробництвом пов'язаних. У зв'язку з цим слід виокремлювати й інші процеси аграрного виробництва, які існують паралельно з названими фазами. Так, не менш важливими є дії, 
спрямовані на підготовку та ремонт сільськогосподарського інструменту та реманенту. На нашу думку, дієслова, якими позначаються такі дії та процеси, варто виокремити підгрупу вербативів лексико-семантичного поля «аграрне виробництво (рослинництво)». До цієї групи, наприклад, відносимо дієслова клепати (косу), гострити (сапу, леміш плуга та ін.).

У лексиконі української мови зафіксовані також дієслова, які доволі опосередковано пов'язані 3 лексико-семантичним полем «аграрне виробництво (рослинництво)». Ідеться про такі вербативи, які позначають дії чи процеси, спрямовані на завдання шкоди аграрному виробництву, зокрема фізичне (механічне) знищення рослин, зокрема й процеси, які відбуваються без активної участі людини: повне чи часткове вимирання рослин внаслідок несприятливих погодних чи кліматичних умов, різноманітні захворювання рослин, їх плодів чи насіння, знищення рослин різними шкідливими комахами чи звірами тощо. Такі дієслівні лексеми також треба об'єднувати в окрему лексико-семантичну групу лексико-семантичного поля «аграрне виробництво (рослинництво)». Це, наприклад, такі дієслова: вирубувати, витоптати (посіви якоїсь рослини), зогнити, засохнути, зів'янути тощо.

На основі виокремлення хронологічно впорядкованих етапів аграрного виробництва (рослинництва), а також процесів, пов'язаних із ними, можемо виділити вісім лексико-семантичних груп дієслів, якими позначаються різноманітні з раніше окреслених етапів, у межах лексико-семантичного поля «аграрне виробництво (рослинництво)»:

1. Дієслова на позначення процесів обробітку грунту: дискувати, боронувати, коткувати, розпушувати, орати, сапати, копати, гноїти, удобрювати та ін. До цього мікрополя належить чимало вузькоспеціальної лексики, професіоналізмів, мотивованих назвами спеіальних пристроїв чи механізмів, якими певним чином оброблюють грунт (дискувати, боронувати, коткувати, чизелювати, культивувати, шлейфувати тощо). Окрім таких однозначних дієслів, основний масив мікрополя становлять бгатозначні лексеми, у сруктурі яких «сільськогосподарська» сема може займати як центральне, ядерне місце (орати, гноїти), так і другорядне, перебуваючи на периферії семеми (бурити, ущільнювати).

2. Дієслова на позначення процесів обробітку насіння (дієслова насінництва): віяти, бактеризувати, вивести (новий сорт), вивіяти, вигрівати, вилузати, лузати, лущцити, вилущити, вимелювати, висуишти, сушити, вичеретувати, відбирати (сортувати), сортувати, відвівати та ін. Варто також зазначити, що інколи багатозначне дієслово може водночас ідентифікуватися 3 різними мікрополями. Наприклад, вербатив лущити має кілька значень, перше з яких («обчищати від шкарлупи, лузки і т. ін., лузати») вказує на віднесеність дієслова до мікрополя назв процесів обробітку насіння, а четверте значення («розпушувати верхній шар грунту (C) Р. В. Познанський, 2013. 
після збирання врожаю») - до мікрополя назв процесів обробітку грунту.

3. Дієслова на позначення процесів садіння чи сіяння насіння: садити, сіяти, висаджувати, висівати, загортати (коренеплоди, напр., картоплю в землю), зронити, заронити (зерно в грунт) та ін.

4. Дієслова на позначення процесів догляду за рослинами під час їхнього росту та дозрівання: щеплювати, акліматизувати, букетувати, полоти, поливати, сапати, тичити, загрібати та ін.

5. Дієслова на позначення процесів збирання урожаю: бункерувати, збирати, зривати, косити, валкувати, жсати, викопати (картоплю), брати (картоплю), виломити (кукурудзу), молотити, витіпати (льон), вичесати (рослинне волокно), иупати (вибірково збирати, напр., картоплю) та ін.

6. Дієслова на позначення процесів підготовки реманенту: вимантачити (гострити мантачкою), клепати (косу), гострити (плуг, сапу), набити (сапy, лопату на держак) та ін.

7. Дієслова на позначення процесів завдання шкоди аграрному господарству: викорінювати, топтати, зрізати, зрубати, зломити, викорчувати, вирвати, поломити (цвіт, гілля), вимивати (з грунту), вирубувати, висмикувати, висмикнути, виснажити (грунт), толочити та ін.

8. Дієслова на позначення процесів, які безпосередньо не здійснюються людиною, зокрема: а) пов'язаних із ростом та дозріванням рослин: брунькуватися, бубнявіти, буйнішати, буяти, визрівати, дозрівати, достигати, викидати (колосся, пуп'янки), колоситися, цзвісти, квітнути, косичитися, кущитися та ін.; б) пов'язаних із знищенням, загибеллю рослин: бур'яніти, глуиити, гнити, гинути, вигорати (від спеки), вимерзати, вимокати, випрівати (гинути під снігом), вироджуватися, висихати, чахнути, відзеленіти, відквітнути, в'янути, жовкнути та ін.

До лексико-семантичного поля «аграрне виробництво (рослинництво)» за окресленими критеріями відносимо понад тисячу дієслів. Усі вони неоднорідно розподіляються між виявленими мікрополями, перебуваючи в їх ядрі чи на периферії. При цьому найчисленнішими є мікрополя дієслів на позначення процесів, які безпосередньо не здійснюються людиною, на позначення процесів збирання урожаю, догляду за рослинами під час їхнього росту та дозрівання, а також дієслова рільництва, тобто на позначення процесів обробітку грунту. Така внутрішня типологія дієслів лексикосемантичного поля «аграрне виробництво (рослинництво)» повною мірою відбиває структуру названого поля й засвідчує неоднорідність аналізованої дієслівної лексики.

\section{Література}

1. Апресян Ю. Д. Экспериментальное исследование семантики русского глагола / Ю. Д. Апресян. - М. : Наука, 1967. - 251 с.

2. Бачкур Р. О. Структура словотвірних парадигм українських назв тварин та рослин : автореф. дис. ... канд. філол. наук : 10.02.01 / Р. О. Бачку. - Івано-Франківськ, 2004. - 20 с. 
3. Богданов В. В. Семантико-синтаксическая организация предложения / В. В. Богданов. - Л. : Наука, 1977. - С. 57-58.

4. Васильев Л. М. Семантика русского глагола / Л. М. Васильев. - М. : Высшая школа, 1981. - $184 \mathrm{c.}$

5. Великий тлумачний словник сучасної української мови / Уклад. голов. ред. В. Т. Бусел. - К. ; Ірпінь : ВТФ «Перун», 2002. - 1440 с.

6. Галайчук В. В. Лексичні одиниці мікросистеми «Рослини» в українських фольклорних текстах : автореф. дис... канд. філол. наук : 10.02.01 / В. В. Галайчук. Львів, 2004. - 20 с.

7. Калько В. В. Когнітивно-ономасіологічний аналіз назв лікарських рослин в українській мові : автореф. дис... канд. філол. наук : 10.02.01 / В. В. Калько. - Одеса, 2003. - 20 с.

8. Караулов Ю. Н. Общая и русская идеография / Ю. Н. Караулов. - М. : Наука, 1976. $-355 \mathrm{c}$.

9. Омельковець Р. С. Номінація лікарських рослин в українському західнополіському говорі : автореф. дис. ... канд. філол. наук : 10.02.01 / Р. С. Омельковець ; НАН України. Ін-т укр. мови. - К., 2004. - 23 с.

10. Пащенко О. М. Семантична стратифікація фітонімічної номенклатури східнослов'янських мов: порівняльно-історичний аспект : автореф. дис. ... канд. філол. наук : 10.02.17 / О. М. Пащенко. - К., 2006. - 19 с.

11. Подолян I. Е. Національна специфіка семантики фітомінів в українській, англійській та німецькій мовах (контрастивний етнопсихолінгвістичний аналіз) : автореф. дис. ... канд. філол. наук : 10.02.17 / І. Е. Подолян. - К., 2000. - 19 с.

12. Почепцов Г. Г. О принципах синтагматической классификации глаголов / Г. Г. Почепцов // Филологические науки. - 1969. - №3.

13. Сердюк А. М. Мотиваційна основа назв рослин у первинному і вторинному семіозисі (на матеріалі української, російської, німецької та французької мов) : автореф. дис. ... канд. філол. наук : 10.02.15 / А. М. Сердюк. - К., 2002. - 20 с.

14. Соколов О. М. Имплицитная морфология русского языка : [монография] / О. М. Соколов. - Нежин : Гідромакс, 2010. - 184 с.

15. Шишліна О. П. Словотвірний потенціал іменників - термінів рослинництва в сучасній німецькій мові (структурно-семантичний і когнітивний аспекти) : автореф. дис. ... канд. філол. наук / О. П. Шишкіна. - Х., 2010. - 20 с.

16. Шумейкіна А. В. Багатозначність дієслів конкретної фізичної дії в сучасній українській літературній мові : автореф. дис. ... канд. філол. наук : 10.02.01 / А. В. Шумейкіна. - К., 2007. - 20 с. 